\title{
FERMENTASI BIJI KECIPIR (Psophocarpus tetragonolobus) OLEH JAMUR TRICHODERMA VIRIDE TERHADAP WARNA, TEKSTUR, DAN SERAT KASAR
}

\author{
WINGED SEED FERMENTATION (Psophocarpus tetragonolobus) BY \\ TRICHODERMA VIRIDE FUNGUS ON COLOR, TEXTURE AND CRUDE FIBER
}

Catur Suci Purwati dan Ludfia Windyasmara

Jurusan Peternakan Fakultas Pertanian, Universitas Veteran Bangun Nusantara, Sukoharjo, 57521, Indonesia

\begin{tabular}{|c|c|}
\hline & ABSTACT \\
\hline $\begin{array}{l}\text { Article history } \\
\text { Accepted: May 4, } 2018 \text {; } \\
\text { Approved: June 1, } 2018 \\
\text { * Corresponding author: } \\
\text { E-mail: } \\
\text { catursuci88@gmail.com }\end{array}$ & $\begin{array}{l}\text { The fermentation process is an activity of microorganisms that make } \\
\text { products with characteristics of texture, flavor, aroma and changes in } \\
\text { nutrient quality that better than the original raw material. It is also protein } \\
\text { process of developing of protein from the material. This study uses a } \\
\text { Completely Randomized Design with four treatments. P0 = Unfermented } \\
\text { winged seeds, } P 1=\text { Winged seeds }+0,1 \% \text { Trichoderma viride mushroom } \\
(T v), P 2=\text { Winged seeds }+0,2 \% \text { Trichoderma viride mushroom (Tv), P3 } \\
=\text { Winged seeds }+0,3 \% \text { Trichoderma viride mushroom (Tv). The material } \\
\text { used was crushed winged seeds as substrates that mixed to be } \\
\text { homogenized. One hundred gr of each sample from every treatment was } \\
\text { weighed, put into a perforated plastic bag (to create anaerobic } \\
\text { atmosphere) with } 2 \mathrm{~cm} \text { thick. Subsequently, samples were incubated in } \\
\text { fermented room at } 30^{\circ} C \text { for } 7 \text { days. Each treatment was repeated } 3 \text { times. } \\
\text { Variables observed in color, texture and coarse fiber. This study indicated } \\
\text { that the winged fermented beans with Trichoderma viride mushroom had } \\
\text { no effect on color, effected crude fiber and texture. }\end{array}$ \\
\hline
\end{tabular}

Keywords: winged Seed fermentation, color, texture and coarse fiber

\section{PENDAHULUAN}

Salah satu alternatif cara yang dapat dilakukan meningkatkan kualitas kimia pada pakan dan menurunkan kandungan $\mathrm{HCN}$ dalam biji kecipir,maka perlu dilakukan pengolahan pakan secra mikrobiologis yaitu fermentasi pakan. Melalui proses fermentasi menggunakan jamur Trichoderma viride, diharapkan mampu meningkatkan kualitas dan tingkat kecernaan. Proses fermentasi merupakan aktivitas mikroorganisme yang dapat menghasilkan produk dengan karakteristik tekstur, flavor, aroma dan perubahan kualitas nutrien yang lebih baik dibandingkan bahan baku asalnya, dan merupakan proses protein enrichment yaitu pengkayaan protein dari bahan tersebut (Gushairiyanto 2004). Beberapa kapang yang sering digunakan dalam bioproses antara lain Aspergillus niger, Aspergillus oryzae, Trichoderma viridae, Trichoderma reseii, Rhizopus oryzae, Rhizopus oligosporus dan Neurospora sitophila (Fardiaz, 1989; Hardjo et al., 1989).

Jamur Trichoderma viride yang berlangsung selama 14 hari, akan menghasilkan tiga enzim selulase yaitu selulase yaitu endo- $\beta$ 1,4-glukanase, ekso $\beta$-1,4-glukanase dan $\beta$ glukosi-dase atau selobiose. Pada penelitian ini media yang digunakan bukan hanya ampas tebu saja, ditambah dengan jagung giling, dedak, dan air yang akan membuat enzim selulase miselium lebih mudah menjangkau substrat, sehingga dapat meningkatkan ketersediaan glukosa sebagai sumber energi bagi mikrobia. 
Sehingga dalam proses fermentasi jamur lebih memilih substrat yang mudah terurai yaitu jagung dan dedak.

\section{METODE PENELITIAN}

Materi yang digunakan dalam penelitian adalah Biji Kecipir (Psophocarpus tetragonolobus), jamur Trichoderma viride yang diperoleh dari UGM Yogyakarta.

Penelitian ini dilakukan dengan menggunakan Rancangan Acak Lengkap dengan empat perlakuan dengan dua ulangan analisis. Perlakuan sebagai berikut :

$$
\begin{aligned}
& \mathrm{P} 0=\text { Biji Kecipir tanpa fermentasi } \\
& \mathrm{P} 1=\text { Biji Kecipir }+0,1 \% \text { jamur } \\
& \text { Trichoderma viride }(\mathrm{Tv}) \\
& \mathrm{P} 2=\text { Biji Kecipir }+0,2 \% \text { jamur } \\
& \text { Trichoderma viride }(\mathrm{Tv}) \\
& \mathrm{P} 3=\text { Biji Kecipir }+0,3 \% \text { jamur } \\
& \text { Trichoderma viride }(\mathrm{Tv})
\end{aligned}
$$

A. Pembuatan ragi Jamur Trichoderma viride

Jamur Trichoderma viride digunakan untuk fermentasi ampas tebu, berasal dari Fakultas Teknologi Pangan UGM yang masih berbentuk inokulum selanjutnya dilakukan perbanyakan dengan media PDA yang dilakukan di laboratorium kimia organik Universitas Bangun Nusantara Sukoharjo. Menimbang media PDA 1,95 gr/50 ml aquadest, kemudian di homogenkan dengan mengunakan steter. Dituangkan kedalam 8 tabung reaksi, kemudian ditutup dengan mengunakan kapas dan selanjutnya dibungkus dengan mengunakan plastik PP. Media di sterilisasi pada suhu $121^{\circ} \mathrm{C}$ selama 15 menit. Setelah disterilisasi kemudian didinginkan selama 1 hari. Jamur Trichoderma Tabel 1. Rerata Warna pada Fermentasi Biji Kecipir (Psophocarpus tetragonolobus) oleh jamur Trichoderma viride viride yang berupa inokulum ditumbuhkan pada media PDA tersebut, dibiarkan tumbuh selama 7 hari.

B. Pembuatan substrat

Biji kecipir dihaluskan mengunakan blender kemudian di over pada suhu $55^{\circ} \mathrm{C}$ selama 24 jam. Substrat yang berupa tepung biji kecipir dihomogenkan dengan cara diaduk kemudian di sterilisasi. Jamur Trichoderma viride yang sudah tumbuh dipanen mengunakan $\mathrm{NaCl} 0,85 \%$, selanjutnya ditumbuhkan di materi substrat selama 7 hari.

C. Pencampuran ragi Jamur Trichoderma viride dengan substrat untuk di fermentasi yang sudah tumbuh dalam substrat di oven pada suhu $55^{\circ} \mathrm{C}$ selama 1 hari. Selanjutnya jamur yang sudah tumbuh dihaluskan dengan mengunakan mixer, setelah ragi jadi akan dicampurkan kedalam substrat yang sudah disterilisasi yang berupa tepung biji kecipir dan dihomogenkan dengan cara diaduk. Masingmasing sampel perlakukan ditimbang sebanyak 100 g,kemudian dimasukkan ke dalam kantong plastik dengan ketebalan $2 \mathrm{~cm}$ dan dilubangi agar tercipta suasana aerob. Selanjutnya diinkubasikan dalam ruang fermentor pada suhu $30^{\circ} \mathrm{C}$ selama 7 hari. Masing-masing perlakuan diulang sebanyak 3 kali. Guna menjaga kelembaban selama proses fermentasi.

\section{HASIL DAN PEMBAHASAN}

\section{Warna}

Warna pada Fermentasi Biji Kecipir (Psophocarpus tetragonolobus) oleh jamur Trichoderma viride
Tahap ketiga Jamur Trichoderma viride

\begin{tabular}{ccccc} 
Trichoderma viride & \multicolumn{3}{c}{} & \\
\hline & \multicolumn{3}{c}{ ULANGAN } & RERATA $^{\text {ns }}$ \\
\cline { 2 - 4 } PERLAKUAN & 1 & 2 & 3 & 1 \\
P0 & 1 & 1 & 1 & 2 \\
P2 & 2 & 2 & 2 & 2 \\
P3 & 2 & 2 & 2 & 2 \\
\hline
\end{tabular}

Keterangan : ${ }^{\mathrm{ns}}=$ non significant $(\mathrm{P}>0,1)$

Hasil analisis variansi menunjukkan bahwa fermentasi biji kecipir (Psophocarpus tetragonolobus) oleh jamur trichoderma viride berbeda tidak nyata terhadap warna.
Warna substrat biji kecipir dan jagung sebelum difermentasi adalah putih kekuningan. Substrat biji kecipir dan jagung yang diberi perlakuan fermentasi mengalami perubahan warna menjadi lebih gelap, hal ini 
menunjukkan bahwa proses fermentasi berhasil.

\section{Tekstur}

Tekstur pada Fermentasi Biji Kecipir (Psophocarpus tetragonolobus) oleh jamur Trichoderma viride

Tabel 2. Rerata Tekstur pada Fermentasi Biji Kecipir (Psophocarpus tetragonolobus) oleh jamur Trichoderma viride

\begin{tabular}{ccccc}
\hline PERLAKUAN & \multicolumn{3}{c}{ ULANGAN } & RERATA \\
\cline { 2 - 4 } & 1 & 2 & 3 & \\
\hline P0 & 1 & 1 & 1 & $1,0^{\mathrm{a}}$ \\
P1 & 1 & 3 & 3 & $2,3^{\mathrm{ab}}$ \\
P2 & 1 & 2 & 2 & $1,6^{\mathrm{ab}}$ \\
P3 & 2 & 3 & 4 & $3,0^{\mathrm{b}}$ \\
\hline
\end{tabular}

Keterangan : Superscript yang berbeda menyatakan ada perbedaan yang nyata $(\mathrm{P}>0,05)$

Hasil analisis variansi menunjukkan bahwa fermentasi biji kecipir (Psophocarpus tetragonolobus) oleh jamur trichoderma viride berpengaruh sangat nyata terhadap tekstur. Hasil penelitian menghasilkan nilai tekstur yang tertinggi pada penambahan $0,3 \%$ jamur trichoderma viride, sedangkan tekstur terendah pada perlakuan biji kecipir tanpa fermentasi.

Biji kecipir dan jagung mempunyai tekstur yang keras, namun pada penelitian ini dihaluskan sehingga menjadi tepung yang lembut. Pada proses fermentasi menggunakan jamur Trichoderma viride telah mengubah tekstur substrat biji kecipir dan jagung yang semula lembut tidak ada gumpalan menjadi lembut dan terdapat gumpalan.

Tabel 3. Rerata Kadar Serat Kasar pada Fermentasi Biji Kecipir (Psophocarpus tetragonolobus) oleh jamur Trichoderma viridae

\begin{tabular}{cc}
\hline Perlakuan & Serat Kasar $(\%)$ \\
\hline P0 & $11,50^{\text {bc }}$ \\
P1 & $7,35^{\mathrm{a}}$ \\
P2 & $10,43^{\mathrm{b}}$ \\
P3 & $11,69^{\mathrm{c}}$ \\
\hline
\end{tabular}

\section{Serat Kasar}

Hasil analisis variansi menunjukkan bahwa fermentasi biji kecipir (Psophocarpus tetragonolobus) oleh jamur trichoderma viridae berpengaruh signifikan $(\mathrm{P}<0,05)$ terhadap kadar serat kasar. Hasil penelitian menghasilkan nilai serat kasar yang paling tinggi adalah pada perlakuan penambahan jamur Trichoderma viridae sebanyak 0,3\% sedangkan serat kasar terendah pada penambahan jamur Trichoderma viridae sebanyak $0,1 \%$.

Keterangan : Superscript yang berbeda menyatakan ada perbedaan signifikan $(\mathrm{P}<0,05)$

Kadar penambahan jamur yang rendah menghasilkan peningkatan kandungan protein murni pun lebih rendah. Hal tersebut disebabkan oleh terbatasnya kesempatan mikroba untuk tumbuh dan berkembang biak sehingga produksi enzim sebagai produk metabolit tidak optimal. Begitu pula dosis inokulum terlalu tinggi menyebabkan zat-zat makanan berkurang sehingga proses fermentasi tidak optimal. Tanuwidjaja (1975) dan Iskandar (2009) menyatakan bahwa jumlah mikroba yang terlalu banyak dapat menyebabkan sporulasi yang terlalu cepat sehingga sebagian energi tidak digunakan untuk memperbanyak sel, begitu pula sebaliknya jumlah mikroba yang sedikit mengakibatkan pertumbuhannya tidak optimal. Lebih lanjut Sulaiman (1988) dan Aisjah 
(1995) mengemukakan bahwa kandungan protein produk fermentasi secara proporsional akan mengalami peningkatan sejalan dengan lama fermentasi sampai batas waktu tertentu, kemudian menurun kembali. Hidayat (2009) mempertegas bahwa fermentasi oleh kapang Rhizopus oligosporus pada waktu 1-30 jam merupakan fase pertumbuhan cepat, terjadi peningkatan suhu dan asam lemak bebas. Pada waktu 30-50 jam merupakan fase transisi dan merupakan fase optimal ditandai dengan penurunan, suhu, dan jumlah asam lemak yang dibebaskan, pertumbuhan kapang tetap, flavor spesifik dan tekstur lebih kompak. Pada waktu 50-90 jam merupakan fase pembusukan ditandai dengan peningkatan jumlah bakteri dan jumlah asam lemak.

\section{KESIMPULAN}

Fermentasi campuran biji kecipir dengan jamur Trichoderma viride tidak berpengaruh terhadap warna, namun berpengaruh pada serat kasar dan tekstur.

\section{DAFTAR PUSTAKA}

[AOAC] Association of Official Analytical Chemist. 1991. Official Methods of Analysis. Arlington, Virginia.

Alderman, G. 1980. Aplication of Pratical Rationing System Agri, SCI. Servis. Ministring OfAgric And Food England.

Anggorodi, R. 1979. Ilmu Makanan Ternak Umum. PT. Gramedia, Jakarta.

Arif, R. 2001. Pengaruh Penggunaan Jerami pada Amoniasi terhadap Daya Cerna NDF, ADF, dan ADS Dalam Ransum Domba Lokal. Jurnal Agroland volume 8 (2) : 208 $-215$.

Arora, S. P. 1989. Pencernaan Mikroba Pada Ruminansia. Gadjah Mada University Press, Yogyakarta.

Church, D. C. 1974. Digestive Physiology and Nutrition of Ruminant.Volume 2. O\&B Books. United Kingdom.

Cowling, E.B. and Kirk, T.K. 1976. Properties of Cellulose and Lignocellulosic Materails as Substrate for Enzymic Conversion Processes. In Enzymic Coversion of Cellulosic Materials : Technology and Applications. Edited by E. L. Gaden Jr., M.H. Mandels, E.T. reese and
L. A. Spano. John Willey and Sons. Inc. New York

Ensminger, M. E. And C. G. Olentine. 1980. Feeds and Nutrition. The Ensminger Publising Company, USA.

Fardiaz, S., 1993. Analisis Mikrobiologi Pangan. P.T. Raja Grafindo Persada, Jakarta.

Gianfreda, L. dan Rao, M.A. (2004). Potential of extra cellular enzymes in remediation of polluted soils: A Review.Enzyme and Microbial Technology 35: 339-354.

Haris, L. E. 1970. Nutrition Research Technique for Domestic and Wild Animal. Animal Science Department Utah State University.

Hetland, H., Choct, M. dan Svihus, B. (2004). Role of in-soluble non-starch polysaccharides in poultry nutrition. World's Poultry Science Journal 60: 415-422.

Li, W.F., Sun, J.Y. dan Xu, Z.R. (2004). Effects of NSP degrading enzyme on in vitro digestion of barley. Asian Australia Journal of Animal Science 17:122-126.

Mahesti, G, 2009. Pemanfaatan Protein pada Domba Lokal Jantan dengan Bobot Badan dan Aras Pemberian Pakan yang Berbeda. Program Studi Magister Ilmu Ternak Program Pasca Sarjana Fakultas Peternakan Universitas Diponegoro, Semarang.

Mulyono, A.M.W., Cahyanto, M.N., Sardjono, Zuprizal, danBachruddin, Z. 2007. Mutasi Trichoderma sp. untukmeningkatkan sekresi selulase. Media Kedokteran Hewan 22: 68-73.

Rose. A.H. 1987. Microbial Enzyme and Bioconversions. Academic Press. London.

Rosningsih, S., 2000. Pengaruh Lama Fermentasi dengan EM4 terhadap Kandungan Nutrien Ekskreta Layer. Buletin Pertanian dan Peternakan. Fakultas Pertanian Universitas Wangsa Manggala. Yogyakarta.1 (2) : 62-69

Parakkasi, A. 1999.Ilmu Nutrisi dan Makanan Ternak Ruminansia. Jakarta Universitas Indonesia Press.

Sophian, Y, 2012. Aktivitas Enzim. Departemen Ilmu Produksi dan Teknologi Peternakan, Institut Pertanian Bogor.

Suparjo. 2000. Analisis Secara Kimiawi. Fakultas Peternakan, Jambi. 
Sutardi. 1980. Landasan Ilmu Nutrisi. Departemen Ilmu Nutrisi dan Makanan Ternak. Fakultas Peternakan IPB. Bogor.

Sutardi, T., N. A. Sigit, dan T. Toharmat. 1983. Standarisasi Mutu Protein Bahan Makanan Ruminansia berdasarkan Parameter Metabolismenya oleh Mikroba Rumen. Laporan Penelitian. Fakultas Peternakan. Institut Pertanian Bogor. Bogor.

Tarmidi, A.R. 2004. Pengaruh Pemberian Ransum Yang mengandung Ampas Tebu Hasil Biokonversi oleh Jamur Tiram Putih (Pleuretus ostreorus) terhadap performans Domba Priangan. Jurnal Penelitian Ilmu Peternakan. Fakultas Pertanian Universitas Padjajaran. Bandung
Tillman, A. D., H. Hartadi, S. Reksohadiprodjo. 1998. Ilmu Makanan Ternak Dasar. Gadjah Mada University Press. Yogyakarta.

Van Soest P. J. 1976. New Chemical Methods for Analysis of Forages for The Purpose of Predicting Nutritive Value. Pref IX International Grassland Cong

Witono, J. A. 2008. Produksi Furfural Dan Turunannya Alternatif Peningkatan Nilai Tambah Ampas Tebu Indonesia. http://www.chem-istry.org/artikel_kimia/teknologi_tepat_guna /produksi_furfural_dan_turunannya_altern atif_peningkatan_nilai_tambah_ampas_teb u_indonesia/. Diakses tanggal 6 Maret 2016 Yitnosumarto, S. 1993. Perancangan Percobaan Analisis dan Interprestasinya. Gramedia Pustaka Utama, Yogyakarta 